\title{
Investigating Urban Ergonomics Features through Healthy City Approach: The Case of Istanbul and Singapore
}

\author{
Çiğdem Canbay Türkyılmaz ${ }^{1}$, Caterina Villani² \\ ${ }^{1}$ Department of Architecture, Faculty of Architecture Y.ldız Technical University, Istanbul, Turkey \\ 2 Department of Architecture and Civil Engineering, City University of Hong Kong, Hong Kong, China \\ ccanbay@yildiz.edu.tr, cvillani2-c@my.cityu.edu.hk \\ Tel: 905552255214
}

\begin{abstract}
This study aims to investigate urban ergonomics features through the healthy city approach. Analytic Hierarchy Process (AHP) is adopted to make a pairwise comparison and ranking of multiple features of urban ergonomics. A small online panel was organized with ten experts of architecture and urban design with a minimum of 10 years of experience. Findings from the literature were shared with these experts, and they were asked to compare the ergonomics features pairwise and rank them. For the next step, two main urban squares from Istanbul and two main public spaces of Singapore are examined.
\end{abstract}

Keywords: Ergonomics; Healthy city; Istanbul; Singapore.

eISSN: 2398-42870 2021. The Authors. Published for AMER ABRA CE-Bs by e-International Publishing House, Ltd., UK. This is an open access article under the CC BYNC-ND license (http://creativecommons.org/licenses/by-nc-nd/4.0). Peer-review under responsibility of AMER (Association of Malaysian Environment-Behaviour Researchers), ABRA (Association of Behavioural Researchers on Asians/Africans/Arabians), and cE-Bs (Centre for Environment-Behaviour Studies), Faculty of Architecture, Planning \& Surveying, Universiti Teknologi MARA, Malaysia.

DOI: https://doi.org/10.21834/ebpj.v6i16.2725

\subsection{Introduction}

The Healthy Cities approach recognizes health determinants and the need to work in collaboration across public, private, voluntary, and community sector organizations. This way of working and thinking includes involving local people in decision-making and requires political commitment and organizational and community development. It recognizes the process to be as important as the outcomes. A thriving and dynamic movement around the world supports this approach. During a rich 30-year history, its evolution and implementation have been deeply innovative and diverse. Nowadays, this approach is more relevant than ever in addressing the established and emerging public health challenges of the 21st century. During the COVID-19 pandemic, healthy cities' importance has been gaining more attention as the 2020 pandemic significantly affected the preconstitued paradigm of urban living (WHO, 2020).

A significant challenge in implementing the Healthy City approach is defining the scale of the urban project. An urban settlement can define various scales from a mega-city to rural villages. According to Clos and Surinach (2018), a better understanding of the type of urban settlements will also be a critical factor in determining access to primary health-care facilities, the potential to improve one's lifestyle, and the opportunities for community engagement to support health procedures. Urban ergonomics, the discipline that aims to make urban areas and infrastructure systems suitable for the life, health, and safety of the citizens within the framework of biological, sociological, and psychological features, could complement the implementation of the Healthy City approach. In this sub-branch of ergonomics, urban environment conditions are adapted to the life of the inhabitant.

eISSN: 2398-42870 2021. The Authors. Published for AMER ABRA cE-Bs by e-International Publishing House, Ltd., UK. This is an open access article under the CC BYNC-ND license (http://creativecommons.org/licenses/by-nc-nd/4.0/). Peer-review under responsibility of AMER (Association of Malaysian Environment-Behaviour Researchers), ABRA (Association of Behavioural Researchers on Asians/Africans/Arabians) and CE-Bs (Centre for Environment-Behaviour Studies), Faculty of Architecture, Planning \& Surveying, Universiti Teknologi MARA, Malaysia.

DOI: https://doi.org/10.21834/ebpj.v6i16.2725 
This study aims to investigate urban ergonomics features through the Healthy City approach. A literature review on Healthy Cities and urban ergonomics are made in the second section. The methodology is explained in the third section. Case studies from Istanbul and Singapore are described, and the results of expert surveys are given in the fifth section. The sixth section discusses the findings concerning the current urban living situation. The last section consists of the conclusion and recommendations.

\subsection{Literature Review}

\subsection{Healthy City Approach}

The Healthy Cities approach was formally established in 1988 as a strategic initiative in the European Region to act as an instrument of WHO's Health for All strategy at the local level (Tsouros, 2015; WHO, 2020). According to the European policy framework Health2020 and the 2030 Agenda for Sustainable Development, a healthy city approach seeks to put health high on the political and social agenda of cities by promoting health, equity, and sustainable development through innovation and change and to build a strong movement for public health at the local level. Successful implementation of this approach requires innovative action addressing health and living conditions and extensive networking between cities across Europe and beyond.

Healthy Cities combined six essential features: (1) local relevance and openness to innovation and a cutting-edge public health agenda; (2) strong leadership and political commitment and a multisectoral approach to health development; (3) partnership-based management of change, transparency, and democratic governance; (4) strategic thinking and planning and concrete deliverables and outcomes; (5) adaptability and receptiveness to emerging needs and ideas; and (6) commitment to solidarity and international and local networking (Tsouros, 2018).

There are at least four prerequisites for sustainable and successful Healthy Cities projects (Tsouros, 2015):

- Strong political commitment to the values and goals of Healthy Cities must be demonstrable and convincing. The aim is to secure the support of the mayor and the city council and ideally support from across the political spectrum and local academic institutions, and voluntary, public, and community sectors.

- Institutional, managerial mechanisms, and structures to support intersectoral work and community participation. A Healthy Cities project cannot reach its potential if reduced to a technical project far from the city's policy and strategy locus.

- A city health profile is essential for prioritizing, monitoring, and driving health accountability in the city. City health profiles should be produced regularly (e.g., at least every two years) and provide information on the health of the population - including health inequalities and information on living and working conditions and lifestyles.

- Healthy Cities engages in formal and informal networking locally, nationally, and internationally and it creates platforms for dialogue, learning, sharing, and consensus-building.

\subsection{Integrating Urban Ergonomics into Healthy City}

Humans tend to transform their habitats to their physical and psychological needs. Whether it is an office desk, a hotel room, or a home, we personalize our surroundings to feel belonging. But public spaces, which are shared among a plethora of urban users, belong to everyone. To achieve the feeling of belonging to the city in public areas, all individuals' physical and psychological needs should determine and reflect the following design criteria.

Public spaces bring together all segments of society and allow experiences, values, and judgments to be shared mutually and explore differences. Thus, it enables the individual to socialize (Madanipour, 2003). Besides, public spaces help urban dwellers establish a sense of social cohesion through festivals and shows or random encounters. Public spaces can be a catalyst for civic engagement. Daily political dialogue, civic engagement, and peaceful activism most frequently occur in main urban public areas in a city (Lennard, 2018).

The field of ergonomics deals with the design or arrangement of the built environment to ensure human efficiency and comfort. Ergonomics criteria are of great importance in the creation of public spaces. Ergonomics standards should not be limited to anthropometric data. In particular, ergonomics' comfort criteria should be considered to ensure individuals' comfort and well-being in public spaces.

Modern society is increasingly aware that human health is inextricably linked with environmental conditions. The comfort of people in public spaces is closely related to the ergonomics organization of the area and the equipment. Urban ergonomics includes the design and organization of public spaces and examines the physical, psychological and social relations between the urban equipment and the users. It covers the standards required for creating urban spaces -from urban facilities to sidewalks, pedestrian roads, pedestrian zones, and squares- where people can feel comfortable. Ergonomics-inspired urban design is an approach that considers the relationship between public spaces and urban dwellers and the optimal benefit for human beings.

Three essential components that direct public space organization in the planning and design process are accessibility, ergonomics criteria, and aesthetic values. Accessibility, which is essentially an equal right of use for all, is directly related to the field of ergonomics. Both ergonomics and aesthetic values should be taken into account in the design and organization of any public spaces (Kutsal Göllü and Canbay Türkyılmaz, 2019).

\subsection{Methodology}

This paper adopts the analytic hierarchy process (AHP), which is a technique that allows to organize and analyze a set of complex decisions (Eberts, 1994; Saaty and Katz, 1990). The aim is to evaluate expert architects and urban designers' opinions on implementing 
urban ergonomics features in the healthy city approach. To reach the purpose, we submitted a brief survey to 10 experts, selected through purposive sampling. Eberts (1994) suggested that the usual minimum sample size for this type of research is six experts in a group. Experts were selected based on their familiarity with the healthy city approach and experience with the Middle Eastern, European, East Asian and South-east Asian urban context. The experts were asked to complete a pairwise comparison and the importance scale of the main urban ergonomics elements highlighted from the literature. The survey consisted of the following parts: (1) Priority of features/main criteria to integrate urban ergonomics into the healthy city (2) The level of priority of a chosen element/criterion compared to the alternative in a scale from 1 (the same emphasis) to 9 (extreme importance).

In the first level of analysis, the surveys' data were examined based on Saaty and Katz (1990) to calculate the priority weights for each criterion. The average of each criterion for every expert was calculated. Each criterion's contribution to the ergonomics implementation into the Healthy city approach was determined by calculations made using the eigenvector. The five most voted criteria were considered in the second level of analysis as crucial elements for the case study analysis.

\subsection{Case Study}

As a case study, two main urban squares from Istanbul and two main public spaces in Singapore -of medium to large and centrally located-are examined. In what follows, the main public space characteristics in these two cities are briefly explained.

Istanbul is one of the world's oldest settlements, with its first settlements dating back about 8000 years (Kuban, 1996). In the 19th century, the urban spaces of Istanbul underwent a significant change. Istanbul entered a rapid development process with the Republic's declaration. Due to the increase in population density, an urban texture in apartment blocks was formed, and the traditional squarestreet-housing relationship gradually decreased. Consumption-oriented spaces, gentrification movements for upper-income groups, and urban transformation projects shape the city for the last two decades (Tarçın Turgay, 2017).

Upon increasing globalization and transnationalism, Southeast Asia is becoming one of the fastest urbanizing areas globally, with a booming population and unprecedented urbanism challenges that will unfold in the coming decades (Bhuyan et al., 2020; Yuen, 2011). Singapore, with only $700 \mathrm{~km} 2$ of land area, is the smallest nation-state of Southeast Asia. In this city-state, public space is present with several historical and social characteristics, scale and programmatic types, loosely distinguished in 1) global city space, 2) historic ethnic district space, 3) public housing developments space (Hee, 2017).

\subsubsection{Istanbul/Kadıköy and Eminönü Square}

Kadıköy Square, located on the Anatolian side of Istanbul, mainly consists of the coastline extending in a "C" shape between Haydarpaşa Train Station and İnciburnu Lighthouse. The Marmara Sea borders its west, and it's east by Rıhtım Avenue, which forms the HaydarpaşaModa line. Söğütlüçeşme Street, one of the main axes of Kadıköy, intersects with Kadıköy Square at its midpoint. This part of the square has lost its character since there are stops for buses and minibus lines between Haydarpaşa Train Station and Eminönü-Karaköy Pier. The chaotic use of the area in question interrupts the relationship of the city dweller with the sea. The fact that it is the intersection point of various transportation networks makes the square a public space that is crowded all day, with intense human movement and diversity (Figure 1.)

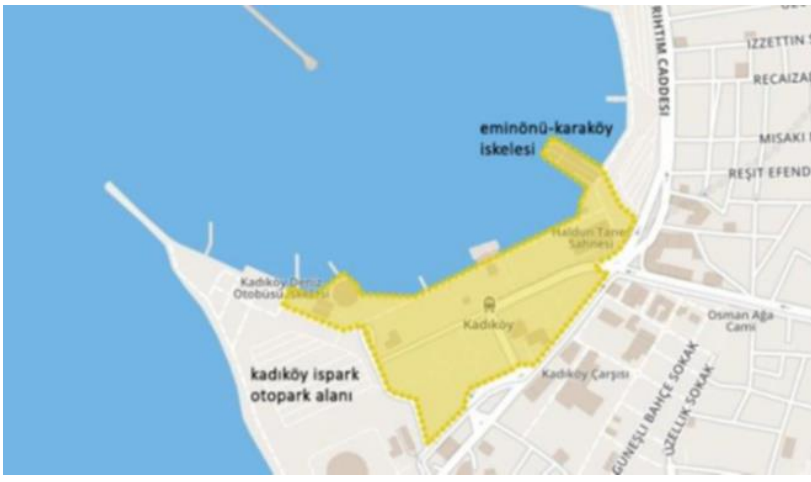

a)

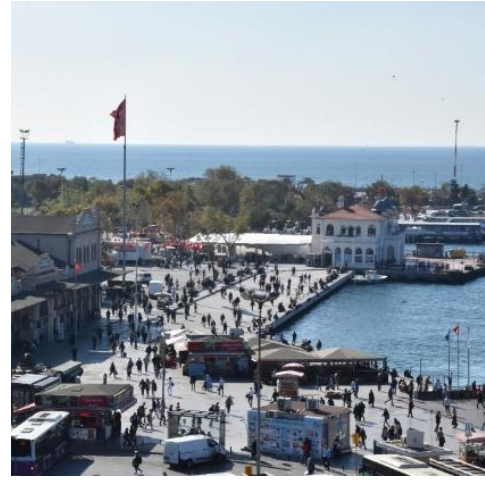

b)

Fig. 1. a) Map of Kadıköy Square b) General view of Kadıköy Square

(Source: Google Maps, istanbulsenin.org)

Kadıköy Square has large green areas. In the northeast of the road dividing the square, there are large shady trees, and in the south-east area are seasonal flowers and trees on the way. However, due to inaccurate urban planning, the relation of green spaces with the sea has been weak.

There are elevation differences that are not suitable for stepping across Kadıköy Square. Due to the coast's filling several times over the years, border stones are seen at different levels. The negativity of the floor covering affects the access of persons with physical disabilities in the square. Also, there are no visible guide surfaces for the visually impaired at any point other than only one end of the square. Although there are ramps in the square, wheelchair access is interrupted at all points considering the whole area. 
Seating elements in Kadıöy Square are randomly positioned on the pedestrian use axis. The seating elements' designs with concrete cast legs with wooden standard seating surfaces meet anthropometric criteria when considered individually. Lighting elements in the square are generally placed parallel to the road and coastline. In areas with high green density, it has been observed that the lighting is insufficient, and dark spots appear. This situation negatively affects visual comfort and creates dangerous places in terms of safety at night use.

There is not enough info sign in Kadıköy Square. The users who are unfamiliar with the area have problems, especially in transportation; it observed that those who descended from public transport could not find the direction to go to or the direction of public transport to reach.

Eminönü Square is one of the most important public open spaces of Istanbul, regarding its location on the European side and its historical importance. It offers an impressive view of Galata, Galata Tower, Golden Horn, and Galata Bridge, with its orientation towards Galata. There are different types of public transportation in the square, such as trams, bus stops, and ferry ports. Although there is an underpass for pedestrians, it is difficult to cross the street and direct the square. The absence of a car park around the square makes it challenging to reach by private vehicle (Figure 2).

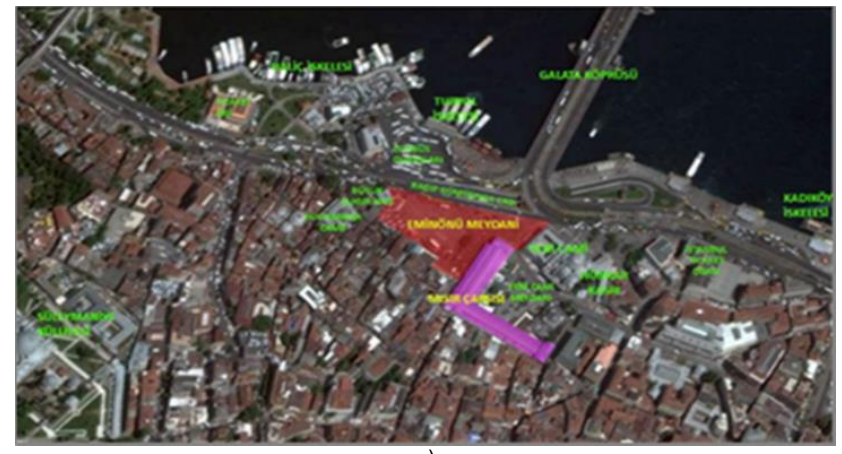

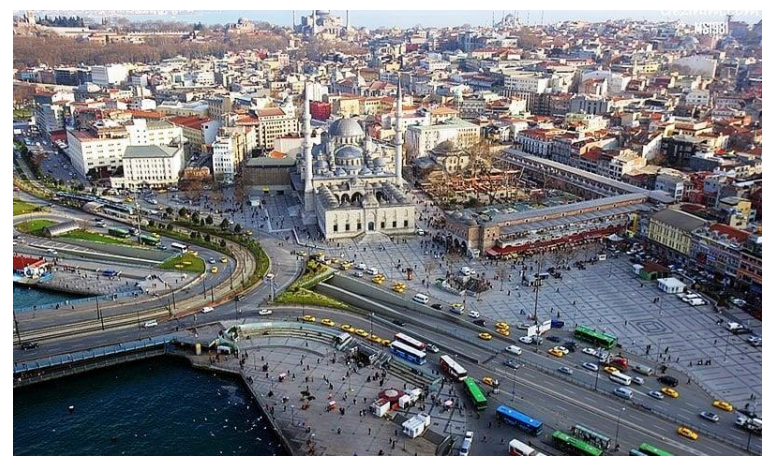

b)

Fig.2 a) Map of Eminönü Square b)General view of Eminönü Square

(Source: Google Maps, istanbeautiful.com)

Eminönü Square has almost no green areas. Eminönü Square is very hot in the warmer months since the trees in the square are tiny, and the shadow areas are inadequate. The sitting units in Eminönü Square are located on the pedestrians' main flow axes or at the intersection points, and this situation has positive effects for the users.

The floor covering material is ergonomically suitable throughout the square. However, there are open points left for the lighting elements at many ends of the floor surrounding. Information signs and boards are becoming more critical, especially in intensive tourism such as Eminönü Square. However, there is no information sign within Eminönü Square. It creates a significant disadvantage for the users.

\subsubsection{Singapore/Orchard Road and Raffles Place}

The two public spaces selected as case studies, Orchard Road and Raffles Place, are in Singapore's core financial and business district, situated south of the Singapore River (Figure 3). Both cases represent the urban configurations of the global city Singapore, shaped by developments re-imagining the city towards globalization since the end of the 20th century. Orchard Road, a $2.3 \mathrm{~km}$ by $50 \mathrm{~m}$ street served by three mass rapid transit stations, is a linear commercial strip prototypical of globalizing Asian space (Villani et al., 2020; Villani and Talamini, 2020, 2021). As in other Asian global cities, this street amasses complex spaces and functions of the city: the colonial heritage, the mass consumption hub, the tourists' attractions, the destination for migrant workers, ex-pat, and the local middle-class community. Besides the several functions and programs, Orchard Road's piecemeal growth physically shapes the elaborate interior and outdoor public spaces, coherently redesigned at the end of the 1990s under the "Ten Year Walkway Masterplan" (Hee, 2017). Today the street is characterized by wide sidewalks, Angsana trees shading the pedestrian space, decorative street lamps and seasonal lightings, railings, CCTV cameras, and some seats. Orchard Road's symbolic status as "the street of the nation" has been chosen to epitomize the government's directions towards a Healthy City approach (the Healthy Lifestyle Campaign) since the end of the 1990s temporary street pedestrianization and mass exercises. Raffles Place was designed at the center of Singapore's commercial hub of the 19th century's Raffles Town Plan. Today this $10700 \mathrm{~m} 2$ square with a garden is served by one mass transit railway, accessed by a colonial heritage facade. The square is bordered by flagship skyscrapers' banks, shaping the island's financial hub. 


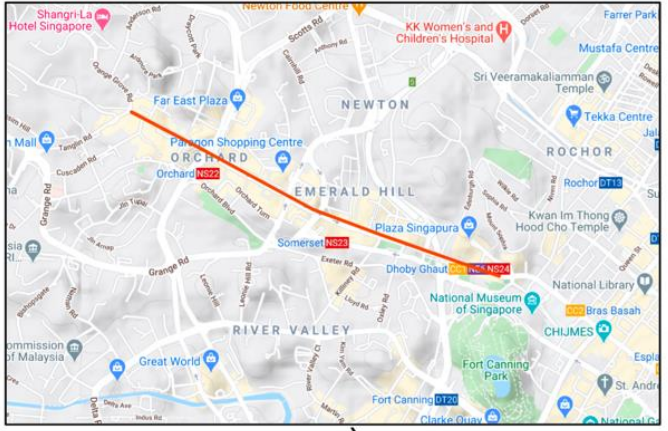

a)

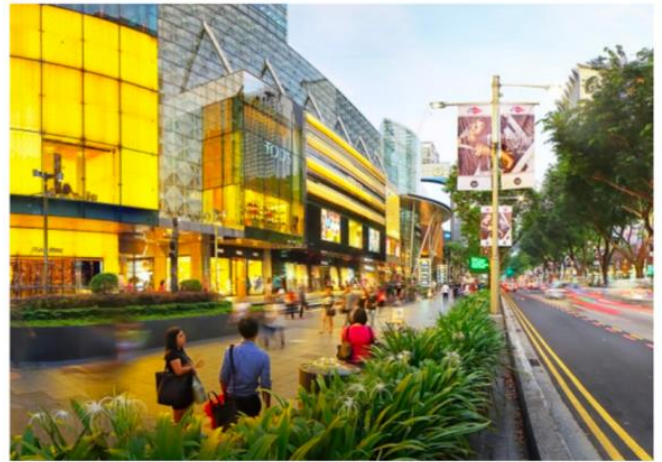

a)

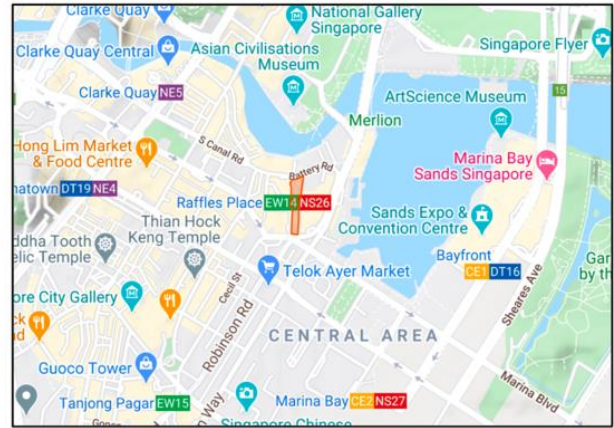

b)

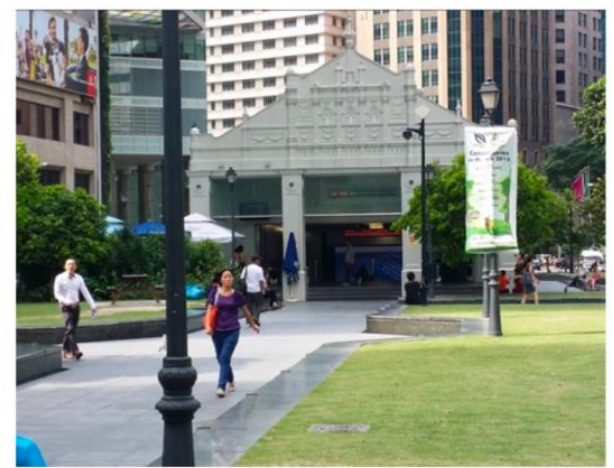

b)

Fig.3 a) Orchard Road, b) Raffles Place

(Source: Google Maps, Nparks.sg.gov)

\subsection{Findings}

\subsection{Result of AHP Survey}

According to findings from the literature, the four main urban ergonomics criteria of a healthy city are safety, sustainability, usability, and health and well-being. These main criteria are also containing sub-criterion groups that define the integration of ergonomics into a healthy city.

- There are seven sub-criterion of "Usability" criteria: street network connectivity, accessibility, the comfort of use, space maintenance and management, visual interest, mobility, and equity. The most important one with $18.13 \%$ of the principal eigenvector is the comfort of use, and the least important one is visual interest with $11.36 \%$ of the principal eigenvector.

- There are four sub-criterion of "Safety" criteria: collective safety, individual safety, social security, and crime prevention. Among them, the most important one with $36,64 \%$ of the principal eigenvector is individual safety, and the least important one is collective safety, with $14.93 \%$ of the principal eigenvector.

- There are five sub-criterion of "sustainability" criteria: energy and material use, natural environment provision, economic performance, production techniques, and the built environment. Among them, the most important one with $38,56 \%$ of the principal eigenvector is natural environment provision, and the least important one is collective safety, with $8.39 \%$ of the principal eigenvector.

- There are six sub-criteria of "health and well-being" criteria: green areas provision, clean water provision, walkability, transportation quality, waste management, and noise control. The most important one with $26.24 \%$ of the principal eigenvector is clean water provision, and the least important one is noise control, with $6.58 \%$ of the principal eigenvector.

According to overall data analysis (Table 1), "Natural environment provision" with $38.56 \%$ of the principal eigenvector is the most crucial urban ergonomics features based on the experts' decisions. The second and the third essential features are "Individual safety" with $36.64 \%$ and "Crime prevention" with $26.49 \%$ principal eigenvector. The least important element is "Noise control" with a $6.58 \%$ principal eigenvector. The results show that the natural environment is the most important of urban ergonomics features. This result coincides with determining the health issue in the urban context, which is stated in the WHO 2020 report. Considering the results, the fact that the safety criterion is one of the essential urban ergonomics factors supports the argument that it is impossible to create healthy living conditions in an environment where people feel insecure. The results regarding this criterion also prove the necessity of ensuring the security of individuals to ensure society's safety. According to the results, the provision of clear water is also a must for forming all sorts of healthy urban environments. 
Table 1. AHP survey results

\begin{tabular}{ll}
\hline Urban Ergonomics criteria & Eigenvector \\
\hline Natural environment provision & $38,56 \%$ \\
Individual safety & $36,64 \%$ \\
Crime prevention & $26,49 \%$ \\
Clean water provision & $26,24 \%$ \\
Energy and material use & $22,44 \%$ \\
Social security & $21,94 \%$ \\
Waste management & $21,74 \%$ \\
Comfort of use & $18,13 \%$ \\
Green areas provision & $18,03 \%$ \\
Built environment & $16,87 \%$ \\
Accessibility & $16,32 \%$ \\
Mobility & $16,29 \%$ \\
Collective safety & $14,93 \%$ \\
Equity & $14,31 \%$ \\
Walkability & $13,77 \%$ \\
Economic performance & $13,74 \%$ \\
Transportation quality & $13,64 \%$ \\
Space maintenance and management & $12,34 \%$ \\
Visual interest & $11,36 \%$ \\
Street network connectivity & $11,24 \%$ \\
Production techniques & $8,39 \%$ \\
Noise control & $6,58 \%$ \\
\hline
\end{tabular}

\subsection{Assessment of The Studies}

Kadıköy Square is not planned sufficiently in terms of urban ergonomics criteria, and it is not possible to find accessibility, ergonomics principles, and aesthetic values that direct the public space organization in Kadıköy Square. Public spaces are open to every user and do not include individuals with disabilities in Kadıköy Square. The visual interaction in urban areas does not take into consideration in Kadıköy Square, and the public needs not fully met in Kadıköy Square. The urban furniture is designed individually as objects suitable for anthropometric measurements. But since they do not create a common language in their relations, they could not generate continuity in Kadıköy Square. The Kadıköy Square-water relationship is limited to the visual effect, and arrangements are not developed in which the city dwellers could directly interact with water. The incompatibility of the ferry ports seen along the coast harms visual perception.

The Eminönü Square is today under-planned, complex, and undefined in terms of ergonomics criteria. The main problem of Eminönü Square is the lack of accessibility factor. Eminönü Square has not been able to show satisfactory performance in terms of urban ergonomics features, and it is also very controversial due to the interventions.

According to the four main urban ergonomics criteria of a healthy city regarding the experts' decision and finding from literature, both Istanbul cases have not been a convenient feature. There are 13 cities/districts from Turkey that have healthy city flagship. Kadıköy district, one of the most prominent regions of Istanbul, has a current flagship Healthy Cities for Phase VI. However, the urban organization of the Kadıköy square is not suitable for a healthy city approach and contains quite inconvenient arrangements.

The first criteria that emerged from AHP analysis are the importance of natural environment provision. The natural environment is present in both Singapore case studies through two different types of landscape. In Orchard Road, the natural environment is not limited to Angsana trees, various bushes, and a considerable flora and fauna populating the linear public space. The street has even a dedicated guide named "Nature Guide to Orchard Road," documenting the rich and three-dimensional natural environment. Due to visitors' continuous flow and the multiple lanes of vehicular traffic, fences and flower boxes make the main green areas not accessible. Conversely, Raffles Place, the central garden consists of several elevated lawn areas accessible and with some seating spaces. The vegetation is not as lush as in Orchard road, making the garden scarcely shaded. The second criteria that emerged from AHP analysis are the importance of individual safety. Singapore is widely considered one of the safest countries globally, with a transparent legal system and low crime rates. Both case studies present a considerable CCTV presence and several hostile architecture designs aiming to restrict behaviors deemed unsafe and prevent crime and maintain order. A balance between urban design elements aiming at limiting behaviors and an accessible and usable public space for all strives to be pursued. The last criteria that emerged from AHP analysis are the importance of clean water provision. Tap water from public drinking fountains and public taps are drinkable in Singapore. The two Singaporean cases, Orchard Road and Raffles Place, present available water in the MRT stations and publicly accessible taps in the commercial buildings near the two areas.

\subsection{Discussion}

According to the findings of this study, the natural environment is the most important urban ergonomics factor determined by AHP analysis. In the organization of public areas, attention should be paid to protecting the natural environment as much as possible. Factors such as air quality, urban water quality, temperature, wind speed are also included in the definition of this natural environment. The protection and sustainability of these factors will continue to be the most crucial factors that ensure the formation and continuity of healthy cities in the future. According to the findings of this study, individual safety is the second urban ergonomics factor. Social distancing will also be a part of individual safety, especially in the ergonomics of post-COVID-19 public spaces. In addition to top-down 
initiatives, certain local leadership and community engagement levels are also crucial to manage and maintain post-Covid public spaces. To ensure the organization of healthy cities and determine post-Covid planning, inclusive actions must first be taken.

Istanbul and Singapore, selected for the case in this study, are two mega-cities with high populations, and they have dense settlements. There may be some thoughts about the inverse proportion between a misperception of a healthy city approach and density. However, studies conducted during the COVID-19 pandemic have shown no strong positive correlation between COVID-19 infection and density (Hamidi et.a.2020; Boterman, 2020). Therefore, as stated in this study, the view that healthy cities' scale can vary from a mega-city to a rural settlement is supported by these findings.

\subsection{Conclusion \& Recommendations}

The pandemic process of 2020, likely to continue until the end of 2021 , has reminded us once again of the importance of living in healthy environments. Public health crises such as the SARS and COVID-19 outbreak have shown that our living spaces, whether private or public, require preparedness for risks beyond just crisis. Preparing our living spaces for health risks and problems will increase urban resilience in the long term.

Not only will inadequate urbanization increase the possibilities of infectious disease transmission, but poorly designed public spaces will discourage healthy lifestyles. Urban ergonomics standards will be one of the most critical design aspects of a healthy city, especially after the Covid-19 pandemic outbreak. There will be new urban design aspects and comfort criteria as well to keep the social distance.

Healthy cities need healthy public spaces. In the arrangement of healthy public spaces, the relationship between urban health and urban dimensions should be handled together with all its technical aspects. At this point, ergonomics can support the healthy urban approach in determining the requirements for providing both physical and psychological comfort conditions and making arrangements following these requirements.

\section{Acknowledgments}

We want to express our great appreciation to 10 experts from Turkey, Hong Kong, and Singapore for their valuable participation in the AHP survey.

\section{Paper Contribution to Related Field of Study}

Few studies are dealing with healthy cities and ergonomics together. Examining the relationship between the healthy city approach and the field of ergonomics and conducting studies in this area will make significant contributions to cities' livability and sustainability.

\section{References}

Bhuyan MR, Lane AP, Moogoor A, et al. (2020) Meaning of age-friendly neighborhood: An exploratory study with older adults and key informants in Singapore. Cities 107: 102940. DOI: 10.1016/j.cities.2020.102940

Bishop, K., \& Said, I., (2017). Challenges of Participatory Qualitative Research in a Malaysian and Australian Hospital. Asian Journal of Environment-Behaviour Studies, 2(4), 1-11.

Boterman,W.R., (2020) Urban-rural polarisation in times of the corona outbreak? The early demographic and geographic patterns of the SARS-CoV-2 epidemic in the Netherlands. Tijds. voor econ. en Soc. Geog. 111, 513-529. https://doi.org/10.1111/ tesg.12437.

Clos J and Surinach R (2018) Health, sustainable development goals and the New Urban Agenda. In: Integrating Human Health into Urban and Transport Planning: A Framework. DOI: 10.1007/978-3-319-74983-9_2.

Eberts RE (1994) User Interface Design. Aventice-hall. https://books.google.com.hk/books/about/User_Interface_Design.html?id=3v0HAQAAMAAJ\&redir_esc=y (accessed 16 February 2021).

Hamidi, S., Sabouri, S., Ewing, R. (2020) Does density aggravate the COVID-19 pandemic?:mearly findings and lessons for planners. J. Am. Plan. Assoc. https://www.tandfonline. com/doi/full/10.1080/01944363.2020.1777891.

Hee L (2017) Constructing Singapore Public Space. Advances in 21st Century Human Settlements. Singapore: Springer Singapore. DOI: 10.1007/978-981-10-2387-3.

Doğan K (1996), İstanbul Bir Kent Tarihi, İstanbul, (in Turkish)

Kutsal Göllü S and Canbay Türkyılmaz Ç (2019) Kent Meydanlarinin Ergonomik Ölçütler Açisindan Değerlendirilmesi: Kadiköy Rihtim Meydani Örneğl. Ergonomi. DOI: 10.33439/ergonomi.479502, (in Turkish).

Lennard SHC (2018) Livable cities: Concepts and role in improving health. In: Integrating Human Health into Urban and Transport Planning: A Framework. DOI: 10.1007/978-3-319-74983-9_4.

Madanipour A (2003) Public and Private Spaces of the City. DOI: $10.4324 / 9780203402856$.

Saaty TL and Katz JM (1990) 'Remarks On The Analytic Hierarchy Process'*. Management Science. 
Tarçın Turgay Z (2017) İstanbul'un Kentsel Yapılanma Süreçlerine Yerel Bir İşletme Üzerinden Bakmak: Neco Kornet Dondurma, Mimarlık 393 (In Turkish)

Tsouros AD (2015) Twenty-seven years of the WHO European Healthy Cities movement: A sustainable movement for change and innovation at the local level. In: Health Promotion International, 2015. DOI: 10.1093/heapro/dav046.

Tsouros AD (2018) Healthy cities: A political movement which empowered local governments to put health and equity high on their agenda. In: Integrating Human Health into Urban and Transport Planning: A Framework. DOI: 10.1007/978-3-319-74983-9_5.

Villani C and Talamini G (2020) Socialising on a Skywalk: How Hong Kong's Elevated Walkways Become Public Open Spaces. Asian Journal of Environment-Behaviour Studies 5(15): 57-72. DOI: 10.21834/aje-bs.v5i15.361.

Villani C and Talamini G (2021) Pedestrianised streets in the global neoliberal city: A battleground between hegemonic strategies of commodification and informal tactics of commoning. Cities 108: 102983. DOI: 10.1016/j.cities.2020.102983.

Villani C, Talamini G and Hu Z (2020) The Patterns of Stationary Activities during COVID-19 Distancing Relaxation: The elevated pedestrian network of Mong Kok, Hong Kong. Environment-Behaviour Proceedings Journal 5(15): 445-452. DOI: 10.21834/ebpj.v5i15.2461.

WHO (2020) Healthy cities effective approach to a rapidly changing world. World Health Organization.

Yuen B (2011) Centenary paper: Urban planning in Southeast Asia: perspective from Singapore. Town Planning Review 82(2): 145-168. DOI: 10.3828/tpr.2011.1 